SHORT REPORTS

\section{Breast feeding trends in Sheffield 1976-82}

The early 1970s saw the nadir of breast feeding in Britain. In Sheffield the proportion of mothers breast feeding at 6 weeks of age had fallen to about $10 \%{ }^{1}$ Low levels of breast feeding were reported from other British centres. ${ }^{2}$

Studies in Sheffield ${ }^{3} 4$ and elsewhere in the early 1970s drew attention to possible harmful effects of artificial feeding. In Sheffield a trend back towards breast feeding began in 1972 and by 1974 was well established. This trend was also reported from other parts of Britain. ${ }^{5}$ A recent national survey has shown that there was a progressive increase in breast feeding in most places between 1975 and 1980. How far this trend will go is still not clear. The data in this paper collected between 1976 and 1982 suggest that there may be a plateau to the level of breast feeding that can be achieved given present circumstances.

\section{Materials and methods}

The infants in this study comprised consecutive attenders at a well baby follow up clinic for infants born in one unit at the Jessop Hospital, Sheffield. Each infant was in his or her 6th or 7th week at the time of the visit. Information was collected on feeding history and social class. Data were collected in the following years (size of sample in parentheses): $1976(n=228), 1977$ $(n=155), 1979(n=322), 1980(n=416), 1981(n=384)$, and $1982(n=201)$. No data were available for 1978 . The attendance rate at the clinic was $92 \%$.

The table shows the proportions of infants in the various social classes in whom breast feeding was attempted during 1977-82. Unfortunately, these data were not collected for 1976 . There was no significant change in the incidence of attempted breast feeding between 1977 and 1982 either in total or within social classes. Analysis of the proportions of babies still breast feeding at 6 weeks showed no significant trend in the period 1976-82.

These data were compared with those previously reported for the period 1971-4 (table). ${ }^{1}$ The sharply rising trend of the earlier period had given way to a plateau. Apart from some apparently random fluctuations there was no significant trend with social class in feeding practice in the period reviewed.

The table also shows the proportions of infants bottle fed at 6 weeks, who were bottle fed from birth, or in whom breast feeding failed.

Proportions of infants breast fed at birth and at 6 weeks of age and proportions bottle fed at 6 weeks of age

\begin{tabular}{|c|c|c|c|c|c|c|c|}
\hline \multirow[b]{2}{*}{ Year } & \multirow[b]{2}{*}{$\begin{array}{l}\text { Social } \\
\text { class }\end{array}$} & \multicolumn{4}{|c|}{$\%$ Breast fed } & \multicolumn{2}{|c|}{$\%$ Bottle fed at 6 weeks } \\
\hline & & $\begin{array}{c}\text { Attempte } \\
\text { breast }\end{array}$ & & $\begin{array}{l}\text { Breast fe } \\
\text { at } 6 \text { week }\end{array}$ & & $\begin{array}{l}\text { By choice } \\
\text { from birth }\end{array}$ & $\begin{array}{c}\text { Started } \\
\text { breast } \\
\text { feeding }\end{array}$ \\
\hline 1971 & - & - & & $10^{*}$ & & - & - \\
\hline 1974 & - & - & & $28^{*}$ & & - & - \\
\hline & I & $=$ & & $\left.\begin{array}{r}65.5 \\
58.6\end{array}\right]$ & & & \\
\hline 1976 & $\begin{array}{l}\text { III } \\
\text { IV } \\
\text { V/VI }\end{array}$ & $\bar{z}$ & & $\left.\begin{array}{l}28.2 \\
33.8 \\
33 \cdot 3\end{array}\right\}$ & 41.0 & - & - \\
\hline 1977 & $\begin{array}{l}\text { I } \\
\text { III } \\
\text { III }\end{array}$ & $\left.\begin{array}{l}85 \cdot 2 \\
65 \cdot 0 \\
80.0\end{array}\right\}$ & $69 \cdot 6$ & $\left.\begin{array}{l}81.4 \\
45.0 \\
60.6\end{array}\right\}$ & $50 \cdot 0$ & $31 \cdot 0$ & $19 \cdot 0$ \\
\hline & $\mathrm{IV} / \mathrm{VI}$ & $\begin{array}{l}64.9 \\
38.5\end{array}$ & & $\begin{array}{l}33 \cdot 8 \\
30 \cdot 8\end{array}$ & & & \\
\hline 1978 & & No data colle & cted & & & & \\
\hline & II & $\left.\begin{array}{l}82 \cdot 1 \\
91 \cdot 5 \\
63.3\end{array}\right\}$ & $69 \cdot 2$ & $\left.\begin{array}{l}71 \cdot 4 \\
79 \cdot 4 \\
41 \cdot 7\end{array}\right\}$ & 51.6 & 28.9 & $20 \cdot 4$ \\
\hline & $\lim _{\mathrm{IV} / \mathrm{VI}}$ & $\left.\begin{array}{l}65.4 \\
66.6\end{array}\right\}$ & & $\left.\begin{array}{l}41.2 \\
40.2 \\
36.4\end{array}\right\}$ & & & \\
\hline & & $\begin{array}{l}80.0 \\
71.9 \\
54.9\end{array}$ & & $\begin{array}{l}74.5 \\
57.3 \\
33.3\end{array}$ & & & \\
\hline 1980 & $\begin{array}{l}\text { III } \\
\text { IV } \\
\text { V/VI }\end{array}$ & $\left.\begin{array}{l}54 \cdot 2 \\
61 \cdot 8 \\
49 \cdot 0\end{array}\right\}$ & $-63 \cdot 2$ & $\left.\begin{array}{l}33 \cdot 3 \\
44.3 \\
34 \cdot 5\end{array}\right\}$ & 47.7 & $36 \cdot 3$ & $15 \cdot 3$ \\
\hline 1981 & II & $\begin{array}{l}86.9 \\
87.3 \\
76.4\end{array}$ & $69 \cdot 8$ & $\left.\begin{array}{l}82.0 \\
72.7 \\
48.6\end{array}\right\}$ & 53.6 & $30 \cdot 2$ & 16.4 \\
\hline & $\lim _{\mathrm{IV} / \mathrm{VI}}$ & $\left.\begin{array}{c}76.4 \\
57.1 \\
58.8\end{array}\right\}$ & & $\left.\begin{array}{l}48.0 \\
22.0 \\
23.5\end{array}\right\}$ & & & \\
\hline & & $\left.\begin{array}{l}87.5 \\
76.9\end{array}\right]$ & & $\left.\begin{array}{l}75 \cdot 0 \\
69 \cdot 2\end{array}\right]$ & & & \\
\hline 1982 & $\left\{\begin{array}{l}\mathrm{III} \\
\mathrm{IV} \\
\mathrm{V} / \mathrm{VI}\end{array}\right.$ & $\left.\begin{array}{r}75.5 \\
63.9 \\
42 \cdot 3\end{array}\right\}$ & $64 \cdot 7$ & $\left.\begin{array}{r}57.1 \\
43.0 \\
34.6\end{array}\right\}$ & 51.9 & $32 \cdot 3$ & $16 \cdot 8$ \\
\hline
\end{tabular}

*Taitz (1976).

\section{Comment}

The 1970s saw a national trend back towards breast feeding. The data presented here agree with those figures in showing that the incidence of breast feeding in the population studied at 6 weeks can be raised to about $50 \%$. They also confirm the relative resistance of social classes IV, V, and VI. The findings suggest that after initial ease in increasing the proportion of breast fed babies, particularly in social classes I, II, and III, a plateau may be reached when it is much more difficult to make further inroads. In the community studied this appears to have occurred about 1977 . Whether subsequent national data will confirm this as a general phenomenon remains to be seen. The exact level of the plateau might depend on the social class mix of the sample.

Most of the babies not breast fed at 6 weeks were bottle fed by choice. Failure of breast feeding accounted for only about one third of those babies bottle fed at 6 weeks. While some babies in social classes I and II are still bottle fed, the main future source for improving the breast feeding rate will be in converting the less educated section of the population to attempt breast feeding. It would appear that a new approach will be needed if further advance is to be achieved entailing an effective programme of antenatal and preconception education, since the maternity services come into contact with parents only once pregnancy has begun and appear to have little influence after a certain level of breast feeding has been attained.

This study was supported by the CHRIS Fund of the Children's Hospital, Sheffield.

${ }^{1}$ Taitz LS. Relationship of infant feeding patterns to weight gain in the first weeks of life. In: The adipose child. Vol 1. Basle: Karger, 1976:60-5.

${ }^{2}$ Department of Health and Social Security. Present day practice in infant feeding. London: HMSO, 1974

${ }^{3}$ Taitz LS, Byers HD. High calorie/osmolar feeding and hypertonic dehydration. Arch Dis Child 1972;47:252, 257-60.

${ }^{4}$ Davies DP. Plasma osmolality and feeding practices of healthy infants in the first three months of life. $\mathrm{Br}$ Med $\mathcal{F} 1973$;ii :340-2.

${ }^{5}$ Martin J, Monk J. Infant feeding 1980. London: Office of Population Censuses and Surveys, 1982.

(Accepted 10 May 1983)

Children's Hospital, Sheffield S10 2TH

L S TAITZ, MD, FRCP, senior lecturer in paediatrics

\section{Silicosis in a Pakistani farmer}

Pneumoconiosis is almost exclusively associated with industry, although inorganic environmental dusts in agricultural communities have been clearly associated with pleural disease. ${ }^{1}$ We report on a farmer 'vho was found to have nodular pulmonary fibrosis due to non-industrial exposure to silica dust.

\section{Case report}

A 77 year old Pakistani man was referred to hospital complaining of vague bilateral chest pains, a recurrent non-productive cough, and mild dyspnoea. There was no history of illness. He had moved to the United Kingdom in 1968 and lived with his daughter and her family, having returned only once to Pakistan for a short stay in 1973. He had been a peasant farmer in Shorkut, west Pakistan, all his life, and had worked in the fields from early childhood. Most of his time had been spent in cultivation, although he had reared some cattle.

There were no abnormalities on examination, but a chest $x$ ray film showed widespread nodular opacities. A Mantoux test with a dilution of $1 / 1000$ produced a reaction of $10 \mathrm{~mm}$ diameter, but tuberculosis was excluded on clinical and bacteriological grounds. Results of pulmonary function tests (and percentages of predicted values) were: forced expiratory volume in 1 second $\left(\mathrm{FEV}_{1}\right) 1.91(81 \%)$; forced vital capacity (FVC) $2.31(65 \%) ; \mathrm{FEV}_{1}$ :FVC $83 \%(143 \%)$; total lung capacity $4.421(71 \%)$; residual volume $2 \cdot 121(87 \%)$; and transfer factor $14 \mathrm{ml} / \mathrm{min} / \mathrm{mm} \mathrm{Hg}(62 \%)$

In the absence of a relevant occupational history fibreoptic bronchoscopy and transbronchial lung biopsy were performed to determine the cause of 
the pulmonary shadowing. Microscopy of the biopsy sample showed large numbers of birefringent needle shaped dust particles associated with nodular interstitial fibrosis (figure), analysis of which, using energy dispersive $x$ ray analysis in an electron microscope, ${ }^{2}$ showed that the particles were made up of muscovite, quartz, kaolin, and rutile with small quantities of feldspar and actinolite; exact measurement was not possible because of the small amount of material available. Results of bulk chemical analysis of the dust deposits were: silica $58.4 \%$; aluminium oxide $20.5 \%$; titanium dioxide $1.5 \%$; iron oxide $9.3 \%$; manganese oxide $0.3 \%$; magnesium oxide $2.9 \%$; sodium oxide $1.7 \%$; and potassium oxide $5.4 \%$.

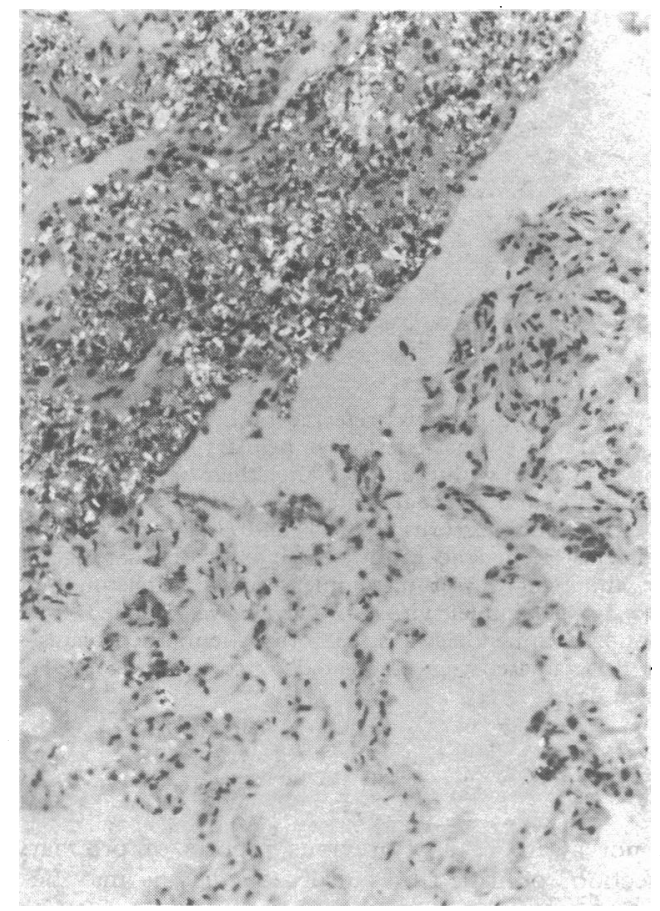

Transbronchial biopsy sample showing edge of collagenous area and birefringent dust particles. Normal lung seen at bottom of picture. Haematoxylin and eosin stain under polarising light $\times 160$ (original magnification).

The finding of nodular pulmonary fibrosis in association with mineral crystals, $58 \%$ of which were silica, confirmed the diagnosis of silicosis. He had been exposed to considerable quantities of dust while working with cattle and behind ox drawn ploughs on the dry soil of the Shorkut region, but a detailed history from both him and his relatives failed to elucidate any other industrial or domestic dust exposure or the use of stone grinding equipment.

\section{Comment}

We concluded that this man developed pneumoconiosis through exposure to environmental dust during a lifetime of farming, the composition of the dust in his lungs-predominantly quartz and clay minerals-being compatible with the diagnosis. Farming does not feature in any list of occupations associated with silicosis, and our diagnosis would have been missed without appropriate histological examination. This emphasises the importance of transbronchial lung biopsy in diagnosing diffuse pulmonary shadowing and the usefulness of dispersive chest $x$ ray analysis in identifying dust in the lung.

Environmental dust disease is not unknown in agricultural workers. A group of Bulgarian farmers working on soils containing high levels of anthophilite, tremolite, and sepiolite were found to have a high incidence of pleural plaques. ${ }^{1}$ In the hot dry climate the soil formed dust with a high fibrous particle content. Silicate pneumoconiosis with interstitial fibrosis but no nodular fibrosis has been described in six agricultural workers in California, five of whom worked in vineyards. ${ }^{3}$ The silica was mainly derived from mica, commonly used as a vehicle for soil additives and pesticides, and the authors speculated that it may have been a marker for toxic soil additives or pesticides. Our patient had never been exposed to such compounds, and his pulmonary fibrosis was a direct result of the inhaled silica. Silicosis has been described in forestry workers in Russia, where the soil was particularly sandy and high concentrations of silica were found in the atmosphere of their tractor cabs.

Agricultural pneumoconiosis should therefore be recognised as a distinct entity that may give rise to $x$ ray shadows similar to those in miliary tuberculosis. It should be considered in immigrants presenting with such chest $x$ ray appearances and a history of farming.

1 Zolov C, Bourkilov L, Bobodjov L. Pleural asbestosis in agricultural workers. Environ Res $1967 ; 1: 287-92$

2 Pooley FD. Electron microscope characteristics of inhaled chrysotile asbestos fibres. $\mathrm{Br} \mathcal{F}$ Ind $\mathrm{Med} 1972 ; 29: 146-53$

${ }^{3}$ Sherwin RP, Barman M, Abraham JL. Silicate pneumoconiosis of farm workers. Lab Invest 1979;40:576-82.

4 Dynnik VI, Khizhniakova LN, Baranenko AA, et al. Silicosis in tractor drivers working on sandy soils on tree farms. Gig Tr Prof Zabol 1981;12: 26-8

(Accepted 29 April 1983)

Department of Chest Medicine, Llandough Hospital, Penarth, South Glamorgan CF6 1XX

A FENNERTY, MB, MRCP, registrar

A M HUNTER, MB, MRCP, senior registrar

A P SMITH, MD, MRCP, consultant

Department of Mineral Exploitation, University College, Cardiff

F D POOLEY, MSC, PHD,

Correspondence to: Dr A Fennerty.

\section{Lactation in diabetic women}

Most mothers in Britain now breast feed their infants. ${ }^{1}$ There is, however, little information on lactation in diabetics and its effects on insulin requirements. ${ }^{2}$

\section{Subjects and results}

We studied 48 insulin dependent diabetics delivered at King's College Hospital, London, to assess the factors affecting lactation in diabetics. There were 20 primaparous and 28 multiparous diabetics (age range 23-40), predominantly $(42 / 48)$ from the non-manual social classes. The duration of diabetes ranged from two to 33 years; 15 women had background retinopathy. They were interviewed before discharge from hospital after delivery and three months later in the outpatient department. The carbohydrate allowance was increased from a mean of $138 \mathrm{~g}$ before pregnancy to $188 \mathrm{~g}$ during lactation as a contribution to the energy needed to produce the daily average of $50 \mathrm{~g}$ carbohydrate (lactose) in the breast milk. No other special advice was given.

Some $\mathbf{4 2}$ diabetic mothers chose to breast feed, and 36 of them were still breast feeding at two weeks, 32 at six weeks, and 27 at three months. These results compare favourably with those in non-diabetic mothers. ${ }^{3}$ Martin and Monk reported that at six weeks $46 \%$ of all mothers were breast feeding in south east England, ${ }^{1}$ compared with our figure of $76 \%$ of the diabetic mothers.

The most important factor for successful lactation was that breast feeding should start very shortly after delivery. In common with the infants of non-diabetic mothers, ${ }^{1}$ those infants of diabetic mothers first put to the breast more than 12 hours after delivery were more likely to be weaned before three months $\left(\chi^{2}=4.32, p<0.05\right.$; see table).

A change in hospital policy one third of the way through the study meant that few infants were separated from their mothers and taken to the special care baby unit. ${ }^{4}$ This change was accompanied by increases from $41 \%$ to $60 \%$ in the number of infants first suckled within 12 hours of delivery and from $53 \%$ to $70 \%$ in the prevalence of breast feeding at three months. Fewer mothers complained of difficulty in getting the infant to grasp the nipple and suck well when breast feeding was initiated early. The diabetic mothers weaned their infants from the breast for the same reasons as non-diabetic mothers, mainly that the supply of milk was insufficient and that the baby refused to suck. ${ }^{13}$ At three months after delivery the mean daily insulin requirement was 43 units compared with 50 units before pregnancy in mothers who were bottle feeding and also lower (40 units,

Time of first suckling and duration of lactation. Figures in parentheses are numbers in each group who had difficulty with suckling

\begin{tabular}{lcccccc}
\hline Hours after birth: & $0-6$ & -12 & -18 & -24 & -30 & -36 \\
\hline $\begin{array}{l}\text { Breast feeding at 3 months } \\
\text { Weaned before 3 months }\end{array}$ & $\begin{array}{l}13(1) \\
4(1)\end{array}$ & $\begin{array}{l}5(1) \\
1(1)\end{array}$ & $\begin{array}{l}1 \\
4(4)\end{array}$ & $\begin{array}{l}8(4) \\
3(1)\end{array}$ & 0 & 0 \\
\hline
\end{tabular}

